\title{
Tobacco industry strategies to prevent a ban on the display of tobacco products and changes to health warning labels on the packaging in Brazil
}

\author{
André Luiz Oliveira da Silva ${ }^{1,2}$, Graziele Grilo ${ }^{3}$, Patricia Aleksitch Castello Branco ${ }^{1}$, Ana Marcia Messeder Sebrão Fer- \\ nandes ${ }^{1}$, Patricia Goncalves Duarte Albertassi' ${ }^{1}$, Josino Costa Moreira ${ }^{2}$
}

\begin{abstract}
INTRODUCTION Through packaging and marketing, the tobacco industry (TI) is able to increase the appeal of its products and reduce the effectiveness of health warning labels (HWLs). Based on scientific evidence and the principles of the WHO Framework Convention on Tobacco Control (FCTC), ANVISA, the Brazilian surveillance and regulatory agency, conducted a process to implement new regulations at the point-of-sale (POS), including a display ban, and new parameters to HWLs. In order to prevent the regulation from entering into force, the TI strategically used several approaches. The objective of this study was to analyze the approaches used by the TI to prevent the implementation of a tobacco display ban and new requirements to HWLs.

METHODS In order to identify and describe TI's approaches, we reviewed several sources of documentation, including published articles, reports, legislation, TI documents, and media stories.

RESULTS Well-known, reported approaches were used by the TI in order to prevent the implementation of new regulations. These approaches included political interference, litigation, and funding studies to question tobacco control measures as previously reported in Brazil and other countries.

conclusions Using established approaches, the TI successfully stopped the implementation of a tobacco display ban and new parameters to HWLs in Brazil.
\end{abstract}

\section{AFFILIATION \\ 1 Agência Nacional de Vigilância, Sanitária, Brasilia, Brazil \\ 2 Escola Nacional de Saúde Pública Sérgio Arouca, Fundação Oswaldo Cruz, Rio de Janeiro, Brazil \\ 3 Johns Hopkins Bloomberg School of Public Health, Institute for Global Tobacco Control, Johns Hopkins University, Baltimore, United States}

CORRESPONDENCE TO

Andre L. Oliveira da Silva.

Laboratório de Toxicologia do

CESTEH/ENSP/FIOCRUZ. R. Leopoldo Bulhões, 1480 - Manguinhos, Rio

de Janeiro - RJ, CEP 21041-210.

E-mail: andre.sp.ensp@gmail.com ORCID ID: https://orcid.org/00000003-4768-959X

\section{KEYWORDS}

tobacco industry, smoking prevention, tobacco display ban, health warnings, tobacco industry strategies, Brazil

Received: 3 June 2020

Revised: 19 August 2020

Accepted: 9 October 2020

\section{INTRODUCTION}

Through marketing and promotion, the tobacco industry (TI) is the vector of an exclusively anthropogenic pandemic: tobacco addiction ${ }^{1}$. TI has a long history of targeting youth to 'replace' smokers and ensure the continuity of its markets ${ }^{1,2}$. Exposure to tobacco marketing and products has been associated with an increase in smoking among adolescents ${ }^{3}$.

The development of attractive packaging is one of the many marketing strategies used to promote tobacco products among youth, increase brand appeal, and create misleading impressions about tobacco products ${ }^{4-6}$. Reviews of TI documents show how cigarette packs are designed to target consumers and increase product appeal ${ }^{7}$, including in Brazil ${ }^{8}$.

To counterattack this strategy, the use of pictorial health warning labels (HWLs) is one of the best 
policies available. Besides decreasing the appeal of tobacco packaging, HWLs also inform consumers about the risks of smoking and stimulate quitting attempts ${ }^{9}$. The WHO Framework Convention on Tobacco Control (FCTC) recommends a series of characteristics to develop effective packaging and labelling of tobacco products ${ }^{10}$.

Considering the existing evidence on the efficacy of regulating packaging and labelling of tobacco products, including health warning labels, the Brazilian Health Regulatory Agency (ANVISA) published in 2010 a public consultation to establish new HWLs requirements and to ban the display of tobacco products at the point-of-sale (POS). This study reviews the approaches used by the TI as a response to the public consultation and analyzes the arguments used to prevent the implementation of the proposed regulations.

\section{METHODS}

We conducted a retrospective, qualitative analysis between January and June 2019. First, we conducted a literature review in PubMed (MEDLINE). Our search strategy included the terms: [tobacco industry] AND [HWLs], which resulted in 145 articles; and [tobacco industry] AND [display bans], which resulted in 88 articles. Our inclusion criteria were: a) papers published in English, Spanish or Portuguese; and b) papers about strategies used by the TI to undermine the implementation of HWLs and/or display bans. After screening, our final sample comprised 34 articles published between 2000 and 2019. The same search strategy was used in SCIELO; however, it did not result in any additional articles.

In order to identify additional documents related to the approaches used by the TI to prevent or minimize the HWLs, we employed snowball search techniques ${ }^{11}$ combining qualitative content techniques with interactive strategies ${ }^{12}$ at the 'Truth Tobacco Industry Documents' (TTID) library ${ }^{13}$. All approaches identified via TTID were described in the scientific articles.

We also examined websites hosted by the TI or its allies, tobacco control organizations, and the federal government; in addition, we reviewed newspapers from Brazil's main tobacco producer region as well as national newspapers to identify other sources of information related to the public consultation and
TI's reactions to it. We monitored legislative activity related to the public consultation via the official websites from the House of Representatives and the Federal Senate and additional internet search ${ }^{14,15}$. We also obtained official material directly from ANVISA regarding the public consultation, including lawsuits, via the Access to Information $\mathrm{Law}^{16}$.

When internal TI documents were cited by one of the sources, we triangulated the information with other documents (e.g. scientific papers, governments reports, FCTC documents) in order to ensure data reliability and reproducibility.

The TI strategies are presented following existing taxonomies on tobacco industry interference as described in Ulucanlar et al. ${ }^{17}$. We chose this taxonomy, because it is internationally accepted and because it has already been used to present and describe IT strategies in Brazil ${ }^{18}$.

\section{RESULTS}

All the approaches used by the TI to undermine the new regulations proposed by ANVISA had been previously reported, and most of them were used to oppose a public consultation held by ANVISA during the discussion on banning additives to tobacco products $^{18}$.

\section{TI resistance to the public consultation}

Brazil was the second country in the world to implement pictorial HWLs on tobacco packaging and is recognized as one of the world leaders in tobacco control. Despite its tobacco control pioneering spirit, the TI has been a fierce opponent with a long history of strategies to prevent or minimize HWLs in tobacco products $^{19}$. In 2010, ANVISA initiated the process to improve Brazil's HWLs by organizing a public consultation $^{20}$ on a proposed resolution to new HWLs.

Published on 28 December 2010, the public consultation, CP 117/2010, invited the population to provide comments to a draft proposal to Resolution $335 / 2003$. The proposal included new tobacco packaging requirements, such as increased HWLs and new warning messages, and a ban on the display of tobacco products at the POS. The consultation lasted from January to April 2011, being the second longest public consultation in ANVISA's history to date (behind only the public consultation regarding tobacco additives) $)^{18,21}$. The draft proposal, in short, 
contained the following provisions:

- New warning message occupying $50 \%$ of the front of the pack: 'Smoking is a disease. You are entitled to treatment'.

- Larger health warning messages on both sides of the pack.

- Mandatory HWLs to secondary packaging.

- Specific warning message to cigars and little cigars: 'These products cause mouth, tongue, and gum cancer and physical and chemical dependency. There are no safe levels to consume these substances'.

- Information provided by TI restricted only to brand name, manufacture date, type of product, quantities, manufacture (or importer) information, bar codes and contacts.

- Ban the use of words, images or any graphic features that could be used to promote or associate the product to: health benefits, relaxing proprieties, added value, promoting (directly or indirectly) the consumption, sexuality, product characteristics, commemorative dates, sports, inducing the use in prohibited places, expressions in languages other than Portuguese.

- New HWLs messages should occupy 60\% of advertising material when displayed at the POS.

- Ban the display of tobacco products at POS, except at tobacco shops.

- Ban the promotional approach of tobacco products.

Contributions to the public consultation were mailed, emailed or hand-delivered to ANVISA ${ }^{22}$. A valid contribution was determined using the same approach of previous wok about TI in Brazil ${ }^{18}$.

Of the 140754 letters received by mail/handdelivered, only 28 were, in effect, a contribution. Of the 1020 participations received by email, 301 were in effect contributions ${ }^{22}$. This public consultation along with the one to ban additives on tobacco products are those that have received more contributions in total. This is of concern because it has been previously reported that this is an approach used by the TI to delay the analysis of the public's comments and, as a result, the implementation of the proposed resolution. The analysis of the documents obtained from ANVISA revealed that ${ }^{18,22,23}$ :

1. Printed forms were used by the TI and supporters to contest the new regulations. These forms contained instructions on how to be filled in. Despite the theme not directly correlated to tobacco cultivation, more than $95 \%$ of participants identified themselves as tobacco growers.

2. Approximately 2000 were blank forms sealed sent directly from the print shop.

3. Most forms were not filled in, preventing the correct identification of the responsible for the contribution.

The TI paid a series of advertisements targeting tobacco growers, small business owners and the general population to spread the idea that the measures proposed by CP $117 / 2010$ would increase illicit trade, negatively affect small business and farmers, affect the product information directed to consumers, and interfere in the consumers' freedom of choice ${ }^{24}$. One of these advertisements published on a national newspaper, in a reference to the letters sent to ANVISA, stated: 'Everybody has their own opinion. In this case, 150000 have the same'24.

These strategies could explain the massive participation of tobacco growers in the public consultation (more than $95 \%$ of participants), who were concerned about the impact of the display ban and larger HWLs.

Similar to one of the approaches used during the additive ban public consultation ${ }^{21}$, a bill was proposed in the national congress (PDC 454/2011) to stop CP 117/2010; in addition, the bill's author used the same argument as to the previous consultation that the resolution interfered with National Congress authority $^{21}$. In 2014, the bill proponent received BRL 40000 (about US\$15000, in 2014 Brazilian Real) from the tobacco company Alliance One ${ }^{25,26}$. In 2013, the author dropped the bill ${ }^{27}$.

The public hearing to discuss CP 117/2010 and CP112/2010 was postponed due TI interventions ${ }^{18}$. Table 1 details the approaches used by the TI during the public commentary process.

\section{TI use of junk science}

The same study conducted by the Getúlio Vargas Foundation (FGV) in 2011 to dispute the additive $\mathrm{ban}^{28}$, funded by the TI and groups linked to $\mathrm{it}^{29}$, concluded that a ban on the display of tobacco products at the POS would increase illicit trade, unemployment and criminal activity, and would result 


\section{Table 1. Discursive and instrumental strategies used by TI to stop the CP117/2010 in Brazil*}

\begin{tabular}{|c|c|c|}
\hline Discursive strategy & Domain & Argument \\
\hline \multirow[t]{4}{*}{$\begin{array}{l}\text { Unanticipated costs to } \\
\text { economy and society }\end{array}$} & \multirow[t]{2}{*}{ Economy } & $\begin{array}{l}\text { Loss of jobs (farmers and POS employees) and sales reduction due to } \\
\text { tobacco display ban }\end{array}$ \\
\hline & & Loss of revenue (due to the increase of illicit trade) \\
\hline & Law enforcement & $\begin{array}{l}\text { Rise of illicit trade - the tobacco display ban and the increase of health } \\
\text { warning message will facilitate the illicit trade }\end{array}$ \\
\hline & Legislation & $\begin{array}{l}\text { ANVISA has no mandate to display ban, change the size and the HWLs } \\
\text { and define POS }\end{array}$ \\
\hline \multirow[t]{2}{*}{$\begin{array}{l}\text { Intended public health } \\
\text { benefits }\end{array}$} & There is not enough evidence & $\begin{array}{l}\text { There is no scientific evidence about the relation between tobacco } \\
\text { display and tobacco use }\end{array}$ \\
\hline & Policy will not work & The measures will not prevent smoking initiation among children \\
\hline $\begin{array}{l}\text { Unintended benefits to } \\
\text { undeserving groups }\end{array}$ & Smugglers will profit & The measures will rise illicit trade \\
\hline $\begin{array}{l}\text { Expected tobacco } \\
\text { industry costs }\end{array}$ & $\begin{array}{l}\text { The tobacco display ban and } \\
\text { increased HWLs with new messages } \\
\text { will reduce sales and jobs }\end{array}$ & $\begin{array}{l}\text { The tobacco display ban and increased HWLs with new messages will } \\
\text { increase illicit trade generating poverty and loss of jobs }\end{array}$ \\
\hline Instrumental strategy & Technique & Description \\
\hline \multirow[t]{2}{*}{ Coalition management } & Constituency recruitment & $\begin{array}{l}\text { TI associations complain and argument to impede the public } \\
\text { consultation }\end{array}$ \\
\hline & Constituency fabrication & $\begin{array}{l}\text { Growers' and restaurants, bars and small shops association complain } \\
\text { about the public consultations }\end{array}$ \\
\hline \multirow{4}{*}{$\begin{array}{l}\text { Information } \\
\text { management }\end{array}$} & \multirow[t]{3}{*}{ Amplification } & Dissemination of $\mathrm{TI}$ arguments in newspapers and other media \\
\hline & & Dissemination of misleading information \\
\hline & & Massive participation against public consultation \\
\hline & Suppression & $\begin{array}{l}\text { 'Scientific studies' funded by TI contesting the tobacco display ban and } \\
\text { increased HWLs with new messages efficacy }\end{array}$ \\
\hline \multirow{4}{*}{$\begin{array}{l}\text { Direct involvement and } \\
\text { influence in policy }\end{array}$} & Incentives and threats & Political campaign funding a political party that defends TI interests \\
\hline & \multirow[t]{2}{*}{ Actor in legislative processes } & $\begin{array}{l}\text { Congressman supported by TI made an amendment in a provisional } \\
\text { measure blocking the implementation of the measures }\end{array}$ \\
\hline & & $\begin{array}{l}\text { Congressman supported by TI tried to cancel the public consultation } \\
\text { through legislative measures }\end{array}$ \\
\hline & Key actor in government & Ministry of agriculture hosts a sectoral group of tobacco chaired by $\mathrm{TI}$ \\
\hline Litigation & $\begin{array}{l}\text { Legal action to contest/obstruct } \\
\text { regulations }\end{array}$ & Injunction to cancel the public hearing \\
\hline
\end{tabular}

POS: point-of-sale. TI: tobacco industry. *Based on the work of Ulucanlar et al. ${ }^{17}$.

in tax revenue losses; therefore, it would not result in any public health benefit ${ }^{28}$. The Pan-American Health Organization (PAHO) reviewed the study and concluded it was biased, the authors had conflicts of interest, and that the arguments were not supported by references ${ }^{30,31}$. The study was also reviewed by other independent researchers, who presented a similar conclusion to $\mathrm{PAHO}^{30}$.

\section{$\mathrm{Tl}$ interference in the National Congress}

In the second half of 2011, a provisional measure on the taxation of tobacco products was approved by federal deputies, receiving several amendments beyond tax, including one that supported the implementation of frontal HWL, but without the message 'Smoking is a disease. You are entitled to treatment'. However, the provisional measure still allowed the display of tobacco products at the $\operatorname{POS}^{32}$.

According to some authors ${ }^{30,31}$, the provisional measure was controversial because some of the proposed amendments were regressive in relation to already established tobacco control polices in 


\section{Table 2. Key arguments used by TI against new requirements to HWLS and a tobacco display ban in Brazil}

TI Arguments
Tobacco display ban is not effective.

Tobacco display ban is not effective.

Increasing the health warning area will reduce product identification, favoring counterfeiting and the illegal market.

The law violates the Brazilian Intellectual Property Law: the right to property, the right to freedom of expression, the right to freedom of initiative, and innovation.

ANVISA has no authority to enact a tobacco display ban and define new health messages.

The regulation will increase illicit trade and facilitate the counterfeit. The graphic warnings in the establishment will cause loss of revenue in other products, as consumers will be discouraged from consuming other products when viewing the impacting images.

the country. For example, one of the amendments would allow smoking in bars and restaurants, which had been prohibited since 1996. None of the regressive amendments was approved; however, the final provisional measure included the new HWL as indicated and did not ban the display of tobacco products at the $\mathrm{POS}^{33}$.

The new legislation expressly allowed the display of tobacco products at the $\mathrm{POS}^{33}$, preempting ANVISA's proposal being discussed in the public consultation CP 117/2010, which ended up being archived. In the end, all efforts related to the consultation did not result in any new tobacco control measure, and the TI successfully prevented the implementation of new HWLs and the display ban in Brazil.

One of the arguments used by a tobacco company against the use of the expression 'Smoking is a disease. Entitled to treatment' was that there was no evidence that another health warning would help to clarify smokers because Brazilian smokers are very well informed about the harms of smoking, and there would be no references to make such a statement ${ }^{23}$. Table 2 summarizes the key arguments used by TI and its allies and provides comments about each argument.

\section{DISCUSSION}

The approaches used by the TI to interfere with the implementation of a tobacco display ban are the same as described in the literature ${ }^{34-37}$. Approaches used by

\section{Comments}

The scientific literature indicates that banning tobacco display is effective to reduce smoking prevalence and initiation ${ }^{52,53}$.

There is no evidence about this relation. On the contrary, HWLs are an evidence-based effective tobacco control measure ${ }^{54}$.

The proposed text was legal; therefore, the legislation had to be amended to make it illegal.

The proposed text was legal; therefore, the legislation had to be amended to make it illegal.

There is no evidence about this relation.

There is no evidence about this relation.

the TI to deter the implementation of the display and new requirements to HWLs were the same as reported in Brazil and in other countries. Nevertheless, in most of the other cases, the TI employed intensive strategies after the implementation of a certain prohibition ${ }^{48-51}$ and not in order to stop a regulation, such as in Brazil.

The TI has used several approaches to undermine evidence-based public health policies ${ }^{34}$. In Brazil, the TI used similar approaches, suggesting that its actions are highly coordinated and organized. Considering that tobacco companies are mostly transnational, the use of similar approaches across the globe is not surprising.

Scientific evidence did not support the main arguments (economic damage and increase of illicit trade) used by the TI and its allies against the tobacco display ban and new requirements to HWLs, which was part of the FGV study funded by the $\mathrm{TI}^{28}$. The lobby used to delay the public consultation process, as a mechanism to thwart regulations, has been described elsewhere, including lobbying activities during the public consultation as a strategy to prevent or at least delay regulation (in other areas of tobacco control policy). Nevertheless, it is worthwhile mentioning that the high number of contributions submitted to ANVISA during the public consultation is unique. Transparency and disclosing conflicts of interests are key measures in policy making, which includes the public's participation. Litigation was used once to avoid the public hearing at the National Institute of Cancer. 


\section{Strengths and limitations}

This was the first study describing a successful TI strategy to prevent tobacco display ban and the larger and more impacting HWLs in Latin America and the Caribbean region. It can explain why almost all countries in this region have not implemented tobacco display bans. The argument analysis could be helpful to other countries to take countermeasures against the TI strategies used in the display ban process in Brazil. The present study describes how the lobby was an important tool used by TI to prevent the implementation of tobacco control policies.

However, not all documents were available, and limitations about the search and indexation of the gray literature involved in this process imposed challenges and difficulties to describe the strategy.

Some information was only available informally or unofficially, which makes its use and discussion impossible. It was not possible to identify all strategies used by IT, especially when it comes to lobbying or the use of front groups.

\section{CONCLUSIONS}

HWLs and a tobacco display ban are evidencebased measures to contain the tobacco epidemic ${ }^{52-54}$. Despite not presenting solid scientific arguments, the TI was able to stop the implementation of these measures. Countries considering the implementation of HWLs and a ban on the display of tobacco products should learn from Brazil's failure in order to prepare themselves to face fierce and extensively documented opposition from TI. Countries must adopt procedures to guarantee transparency, especially to avoid conflicts of interest between the industry and public health policymakers. In this case, the TI was successful through its lobbying activities, thus pro-health lobby strategies and popular campaigns could be used as a response. The approaches used by TI are extensively known and tobacco control supporters should consider strategies to counterattack those of the TI before they even happen.

The TI strategies are global and very similar around the world; this reinforces the need to share experience and strength and apply FCTC Articles 20 (Research, surveillance, and exchange of information), 21 (Reporting and exchange of information), and 22 (Cooperation in the scientific, technical and legal fields and provision of related expertise).

\section{REFERENCES}

1. World Health Organization. WHO Report on the Global Tobacco Epidemic, 2008: The MPOWER package. Geneva, Switzerland: World Health Organization; 2008. https://apps.who.int/iris/ bitstream/handle/10665/43818/9789241596282_eng. pdf?sequence=1. Accessed June 12, 2019.

2. Soto Mas F, García León FJ. La industria tabaquera y la promoción del tabaquismo entre los menores y jóvenes: una revisión internacional. Gac Sanit. 2009;23(5):448457. doi:10.1016/j.gaceta.2009.04.004

3. Lovato C, Watts A, Stead LF. Impact of tobacco advertising and promotion on increasing adolescent smoking behaviours. Cochrane Database Syst Rev. 2011;2011(10):CD003439. doi:10.1002/14651858.CD003439.pub2

4. Hammond D, Dockrell M, Arnott D, et al. Cigarette pack design and perceptions of risk among UK adults and youth. Eur J Public Health. 2009;19(6):631-637. doi:10.1093/eurpub/ckp122

5. Bansal-Travers M, Hammond D, Smith P, et al. The impact of cigarette pack design, descriptors, and warning labels on risk perception in the U.S. Am J Prev Med. 2011;40(6):674-682. doi:10.1016/j.amepre.2011.01.021

6. Gallopel-Morvan K, Moodie C, Hammond D, et al. Consumer perceptions of cigarette pack design in France: a comparison of regular, limited edition and plain packaging. Tob Control. 2012;21(5):502-506. doi:10.1136/tobaccocontrol-2011-050079

7. Kotnowski K, Hammond D. The impact of cigarette pack shape, size and opening: evidence from tobacco company documents. Addict Abingdon Engl. 2013;108(9):16581668. doi:10.1111/add.12183

8. Islam F, Thrasher JF, Szklo A, et al. Cigarette flavors, package shape, and cigarette brand perceptions: an experiment among young Brazilian women. Rev Panam Salud Pública. 2018;42:1-9. doi:10.26633/rpsp.2018.5

9. Hammond D. Health warning messages on tobacco products: a review. Tob Control. 2011;20(5):327-337. doi:10.1136/tc.2010.037630

10. WHO Framework Convention on Tobacco Control. Guidelines for implementation of Article 11: Packaging and labelling of tobacco products. http://www.who. int/fctc/treaty_instruments/adopted/article_11/en/. Published 2008. Accessed June 12, 2019.

11. Anderson SJ, McCandless PM, Klausner K, et al. Tobacco documents research methodology. Tob Control. 2011;20(Suppl 2):ii8-ii11. doi:10.1136/tc.2010.041921

12. Bero L. Implications of the tobacco industry documents for public health and policy. Annu Rev Public Health. 2003;24(1):267-288. doi:10.1146/annurev.publhealth.24.100901.140813

13. Roper Organization Inc. A Study of Smokers' Habits and Attitudes with Special Emphasis on Low Tar and Menthol Cigarettes. Vol II. In: Truth Tobacco Industry Documents: Philip Morris Records. https:// www.industrydocumentslibrary.ucsf.edu/tobacco/ 
docs/\#id=mzyw0189. Published 1979. Accessed June 26, 2018.

14. Portal da Câmara dos Deputados Website. http://www2. camara.leg.br/. Accessed July 9, 2017.

15. Senado Federal Website. http://www12.senado.leg.br/ hpsenado. Accessed July 9, 2017.

16. Presidência da República Casa Civil, Subchefia para Assuntos Jurídicos. LEI No 12.527, DE 18 DE NOVEMBRO DE 2011. http://www.planalto.gov. br/ccivil_03/_ato2011-2014/2011/lei/112527.htm. Accessed July 9, 2017.

17. Ulucanlar S, Fooks GJ, Gilmore AB. The Policy Dystopia Model: An Interpretive Analysis of Tobacco Industry Political Activity. PLOS Med. 2016;13(9):e1002125. doi:10.1371/journal.pmed.1002125

18. Silva ALO da, Bialous SA, Albertassi PGD, et al. The taste of smoke: tobacco industry strategies to prevent the prohibition of additives in tobacco products in Brazil. Tob Control. 2019;28(e2):e92-e101. doi:10.1136/tobaccocontrol-2018-054892

19. Perez C, Silva VL, Bialous SA, et al. Analysis of the tobacco industry's interference in the enforcement of health warnings on tobacco products in Brazil. Cad Saúde Pública. 2017;33(Suppl 3). doi:10.1590/0102-311x00120715

20. Agência Nacional de Vigilância Sanitária. Consulta Pública no 117 de 27/12/2010 - Proposta de Revisão da RDC $335 / 2003$, que dispõe sobre as embalagens e os materiais de propaganda dos produtos fumígenos derivados do tabaco. http://portal.anvisa.gov.br/consultas-publicas\#/ visualizar/25601. Accessed June 12, 2019.

21. Agência Nacional de Vigilância Sanitária. Consultas Públicas - Anvisa. http://portal.anvisa.gov.br/consultaspublicas. Accessed November 17, 2017.

22. Agência Nacional de Vigilância Sanitária. Apresentação dos Resultados da Consulta Pública 117/2010 - Audiência Pública número 03/2011. Brasília, DF: Anvisa; 2011.

23. Agência Nacional de Vigilância Sanitária/ Gerência de Produtos de Tabaco. CP 117/2010 - avaliação das contribuições. Brasília, DF: GPDTA, ANVISA; 2016.

24. Aliança de Controle do Tabagismo, Action on Smoking and Health. Tabaconomics: Como as grandes empresas de tabaco usam dados duvidosos para minar as políticas de saúde (translated and adapted by ACTBr). http:// actbr.org.br/uploads/arquivo/739_tabaconomics.pdf. Published 2012. Accessed June 14, 2019.

25. Tribunal Superior Eleitoral. Prestação de contas Eleitorais - Eleição 2014. SPCE WEB. http://inter01.tse.jus.br/ spceweb.consulta.receitasdespesas2014/. Accessed June $14,2019$.

26. Observatório sobre as Estratégias da Indústria do Tabaco. Alceu Moreira. http://observatoriotabaco.ensp.fiocruz.br/ index.php/Alceu_Moreira. Accessed August 3, 2020.

27. Camara dos Deputados. PDC 454/2011 - Projeto de Decreto Legislativo. https://www.camara.leg.br/proposicoesWeb/ fichadetramitacao?idProposicao=521922. Published 2011.
Accessed June 14, 2019.

28. FGV Projetos. Estudo dos Efeitos Socioeconômicos da Regulamentação, pela ANVISA, dos Assuntos que tratam as Consultas Públicas no 112 e 117. https://fgvprojetos. fgv.br/publicacao/estudo-de-efeitos-socioeconomicosda-regulamentacao-dos-assuntos-das-consultas-publicas. Published 2011. Accessed June 2, 2019.

29. Observatório sobre as Estratégias da Indústria do Tabaco. Categoria:Organizações ligadas ao tabaco. http://cetab.ensp.fiocruz.br/index.php/ Categoria:Organiza\%C3\%A7\%C3\%B5es_ligadas_ao_

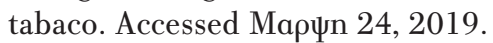

30. Cavalcante TM, Pinho MCM, Perez C, et al. Brasil: balanço da Política Nacional de Controle do Tabaco na última década e dilemas. Cad Saúde Pública. 2017;33(Suppl 3). doi:10.1590/0102-311x00138315

31. Leonardo Henriques Portes. A política de controle do tabaco no brasil de 1986 a 2016: contexto, trajetória e desafios. Rio de Janeiro, Brazil: Ministerio da Saude; 2017. http://bvssp.icict.fiocruz.br/lildbi/docsonline/get. php?id=5023. Accessed August 3, 2020.

32. Camara dos Deputados. MPV 540/2011: Medida Provisória. https://www.camara.leg.br/proposicoesWeb/ fichadetramitacao?idProposicao=513512. Published 2011. Accessed August 3, 2020.

33. Presidência da República Casa Civil, Subchefia para Assuntos Jurídicos. LEI No 12.546, DE 14 DE DEZEMBRO DE 2011. http://www.planalto.gov.br/ ccivil_03/_Ato2011-2014/2011/Lei/L12546.htm. Accessed June 17, 2019.

34. Saloojee Y, Dagli E. Tobacco industry tactics for resisting public policy on health. Bull World Health Organ. 2000;78(7):902-910. https://www.who.int/bulletin/ archives/78(7)902.pdf. Accessed August 3, 2020.

35. Assunta M, Fields N, Knight J, et al. 'Care and feeding': the Asian environmental tobacco smoke consultants programme. Tob Control. 2004;13(Suppl 2):ii4-ii12. doi:10.1136/tc.2003.005199

36. MacKenzie R, Collin J, Sriwongcharoen K, et al. 'If we can just 'stall' new unfriendly legislations, the scoreboard is already in our favour': transnational tobacco companies and ingredients disclosure in Thailand. Tob Control. 2004;13(Suppl 2):ii79-ii87. doi:10.1136/tc.2004.009233

37. Bialous SA, Shatenstein S. Profits Over People: Tobacco Industry Activities to Market Cigarettes and Undermine Public Health in Latin America and the Caribbean. Washington, DC: Pan American Health Organization; 2002. https://escholarship.org/uc/item/82r4v193\#main. Accessed March 23, 2018.

38. Muggli ME, Hurt RD, Repace J. The tobacco industry's political efforts to derail the EPA report on ETS. Am J Prev Med. 2004;26(2):167-177. doi:10.1016/j.amepre.2003.10.015

39. Lee S, Ling PM, Glantz SA. The vector of the tobacco epidemic: tobacco industry practices in low and middleincome countries. Cancer Causes Control. 2012;23(Suppl 
1):117-129. doi:10.1007/s10552-012-9914-0

40. Landman A, Glantz SA. Tobacco Industry Efforts to Undermine Policy-Relevant Research. Am J Public Health. 2009;99(1):45-58. doi:10.2105/AJPH.2007.130740

41. Bialous SA, Peeters S. A brief overview of the tobacco industry in the last 20 years. Tob Control. 2012;21(2):9294. doi:10.1136/tobaccocontrol-2011-050395

42. Allen M. Confronting the vector of tobacco-related disease. Am J Law Med. 2013;39(2-3):308-331. doi:10.1177/009885881303900207

43. Yach D, Bialous SA. Junking Science to Promote Tobacco. Am J Public Health. 2001;91(11):1745-1748. doi:10.2105/AJPH.91.11.1745

44. Barnoya J, Glantz S. Tobacco industry success in preventing regulation of secondhand smoke in Latin America: the 'Latin Project'. Tob Control. 2002;11(4):305314. doi:10.1136/tc.11.4.305

45. Sebrié EM, Barnoya J, Pérez-Stable EJ, et al. Tobacco industry successfully prevented tobacco control legislation in Argentina. Tob Control. 2005;14(5):e2. doi:10.1136/tc.2005.011130

46. Ibrahim JK, Glantz SA. Tobacco industry litigation strategies to oppose tobacco control media campaigns. Tob Control. 2006;15(1):50-58. doi:10.1136/tc.2005.014142

47. Balwicki Ł, Stokłosa M, Balwicka-Szczyrba M, et al. Tobacco industry interference with tobacco control policies in Poland: legal aspects and industry practices. Tob Control. 2016;25(5):521526. doi:10.1136/tobaccocontrol-2015-052582

48. Christie B. Ban on tobacco display to go ahead in Scotland after court ruling. BMJ. 2012;345:e8490. doi:10.1136/bmj.e8490

49. Huong LTT, Long TK, Son PX, et al. Violation of Bans on Tobacco Advertising and Promotion at Points of Sale in Viet Nam: Trend from 2009 - 2015. Asian Pac J Cancer Prev. 2016;17(S1):91-96. doi:10.7314/apjcp.2016.17.s1.91

50. Eadie D, Stead M, MacKintosh AM, et al. Are Retail Outlets Complying with National Legislation to Protect Children from Exposure to Tobacco Displays at Point of Sale? Results from the First Compliance Study in the UK. PloS One. 2016;11(3):e0152178. doi:10.1371/journal.pone.0152178

51. Stead M, Eadie D, Purves RI, et al. Tobacco companies' use of retailer incentives after a ban on point-of-sale tobacco displays in Scotland. Tob Control. 2018;27(4):414-419. doi:10.1136/tobaccocontrol-2017-053724

52. He Y, Shang C, Huang J, et al. Global evidence on the effect of point-of-sale display bans on smoking prevalence. Tob Control. 2018;27(e2):e98-e104. doi:10.1136/tobaccocontrol-2017-053996

53. Li L, Borland R, Yong H-H, et al. Impact of Point-ofSale Tobacco Display Bans in Thailand: Findings from the International Tobacco Control (ITC) Southeast Asia Survey. Int J Env Res Public Health. 2015;12(8):95089522. doi:10.3390/ijerph120809508

54. Hammond D, Fong GT, McNeill A, et al. Effectiveness of cigarette warning labels in informing smokers about the risks of smoking: findings from the International Tobacco Control (ITG) Four Country Survey. Tob Control. 2006;15(Suppl 3):iii19-iii25. doi:10.1136/tc.2005.012294

\section{ACKNOWLEDGEMENTS}

The authors thank ANVISA and FIOCRUZ. This article represents solely and exclusively the opinions and views of the authors, based on the evidence available at the time. It does not represent ANVISA, FIOCRUZ, Ministry of Health or the Brazilian Government's institutional views, policies, or opinions.

\section{CONFLICTS OF INTEREST}

The authors have completed and submitted the ICMJE Form for Disclosure of Potential Conflicts of Interest and none was reported.

\section{FUNDING}

There was no source of funding for this research.

PROVENANCE AND PEER REVIEW

Not commissioned; externally peer reviewed. 